\title{
Comparative Study of the Genetic Variability of Sitophilus Zeamais Subservient to 2 Host Plants (Millet and Maize) in Senegal (West Africa)
}

\author{
Ngagne Demba Sarr*, Dethie Ngom, Mbacke Sembene \\ Faculty of Sciences and Technology (Fst), University Cheikh Anta DIOP (UCAD), Dakar, Republic of Senegal
}

Email address:

ngagnedembasarr@gmail.com (N. D. Sarr)

${ }^{*}$ Corresponding author

\section{To cite this article:}

Ngagne Demba Sarr, Dethie Ngom, Mbacke Sembene. Comparative Study of the Genetic Variability of Sitophilus Zeamais Subservient to 2 Host Plants (Millet and Maize) in Senegal (West Africa). American Journal of BioScience. Vol. 7, No. 3, 2019, pp. 71-76. doi: 10.11648/j.ajbio.20190703.12

Received: August 21, 2019; Accepted: September 20, 2019; Published: September 30, 2019

\begin{abstract}
Millet and maize, because of the importance of their yields, constitute a reliable alternative to the question of sovereignty and food security. These cereals are exploited in all agroecological zones of Senegal. But their stocks, especially those of maize, are deteriorated by Sitophilus Zeamais, a beetle of the Curculionidae. It is therefore necessary to find natural solutions that are healthier than the use of pesticides which is harmful to living beings and the environment. This article makes a comparative study of the genetic diversity of the populations of this insect individually subservient to maize and to millet. The importance of this study is to find a genetic explanation for the differential vulnerability of these host plants to Sitophilus Zeamais, because the genetic diversity influences the adaptability of the individual and consequently its development. For this, insects Sitophilus Zeamais subservient on the one hand to maize and on the other hand to millet were collected in each agroecological zone. The exploitation of 125 sequences of the Cytochrome B gene corresponding to the individuals, by software of study in population genetics (Bioedit, DNAsp, Mega, Arlequin...) compared to parameters of genetic variability, revealed an approximately similar and high genetic diversity of the 2 populations of millet and maize. Thus, millet and maize genetically have the same effect on the adaptability of Sitophilus Zeamais.
\end{abstract}

Keywords: Cytochrome B, Maize, Millet, Sitophilus Zeamais, Genetic Diversity

\section{Introduction}

In Senegal, maize and millet constitute the food base of households, especially rural households. These 2 cereals occupy respectively $28 \%$ and $11 \%$ in rural areas against respectively $19 \%$ and $5 \%$ in urban areas [14]. But their stocks are altered by a powerful pest, a coleopterous beetle of the Curculionidae, named Sitophilus Zeamais. According to Ngamo and Hance, losses can range from $25 \%$ to $40 \%$ in six months of storage [14]. Thus, the extent of the damage threatens the socio-economic function that these cereals can play in a current context of poverty reduction.

The search for solutions to drastically reduce these losses has always been to find the most effective pesticide to eliminate the insect. No genetic study to correlate host plants populations with the extent of damage which they are individually victim has been done.

Our study aims to identify the host plant most favorable to the survival or extinction of Sitophilus Zeamais, by the comparative exploitation of the genetic diversity of the 2 populations of millet and of maize. Indeed, homogeneity and genetic heterogeneity affect the adaptive potential of the insect.

To achieve our objective, we sampled in each agroecological zone insects subservient on the one hand to millet and subservient on the other hand to maize, on stocks and fields widely spaced. A total of 125 individuals were harvested, of which 72 from maize and 53 from millet.

The sequences of the Cytochrome B gene corresponding to these individuals have been exploited by population genetics software (Bioedit, DNAsp, Mega, Harlequin...), with respect to parameters of genetic variability (haplotypic and 
nucleotide diversity, number of haplotypes, number of parsimony or singleton variable sites and invariable, average number of nucleotide differences...), in relation to our objective.

\section{Material and Methods}

\subsection{Sampling}

\subsubsection{Sampling Localities}

Individuals of Sitophilus zeamais were sampled in 4 agroecological zones (AEZ) of Senegal, on 2 host plants (Millet and Maize). The choice given to these zones is justified by their vocation naturally agricultural and by ecological and geographical characteristics which specify each of them. As for millet and maize, they were chosen for their socio-economic functions and their very high vulnerability to the insect. These agroecological zones are constituted by the AEZ of NBA (Nord Bassin Arachidier)

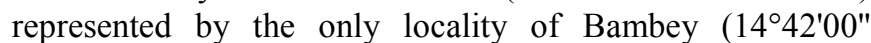
Nord $/ 16^{\circ} 27^{\prime} 00^{\prime \prime}$ Ouest), the AEZ of the SBA (Sud Bassin Arachidier) to Keur Ayip (1336'00" North/15³7'00" Ouest), to Mbassis $\left(14^{\circ} 04^{\prime} 60^{\prime \prime}\right.$ Nord $/ 16^{\circ} 25^{\prime} 60^{\prime \prime}$ West), to Nioro (15 $13^{\prime} 55^{\prime \prime}$ North/09 $35^{\prime} 37^{\prime \prime}$ West) and Dionewar (13 ${ }^{\circ} 52^{\prime} 60^{\prime \prime}$ North $/ 16^{\circ} 43^{\prime} 60^{\prime \prime}$ West). Samples were also taken from the AEZ of SOHC (Senegal Oriental Haute Casamance) at Missirah $\left(13^{\circ} 41^{\prime} 00^{\prime \prime}\right.$ Nord $/ 16^{\circ} 30^{\prime} 01^{\prime \prime}$ Ouest) and Salémata $\left(12^{\circ} 37^{\prime} 60^{\prime \prime}\right.$ North/12 $49^{\prime} 00^{\prime \prime}$ West). The other AEZ sampled is BMC (Basse Moyenne Casamance) in The Gambia

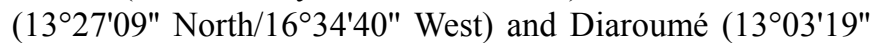
North/15'38'34" West). Figure 1 summarizes the sampling sites and their respective AEZs.

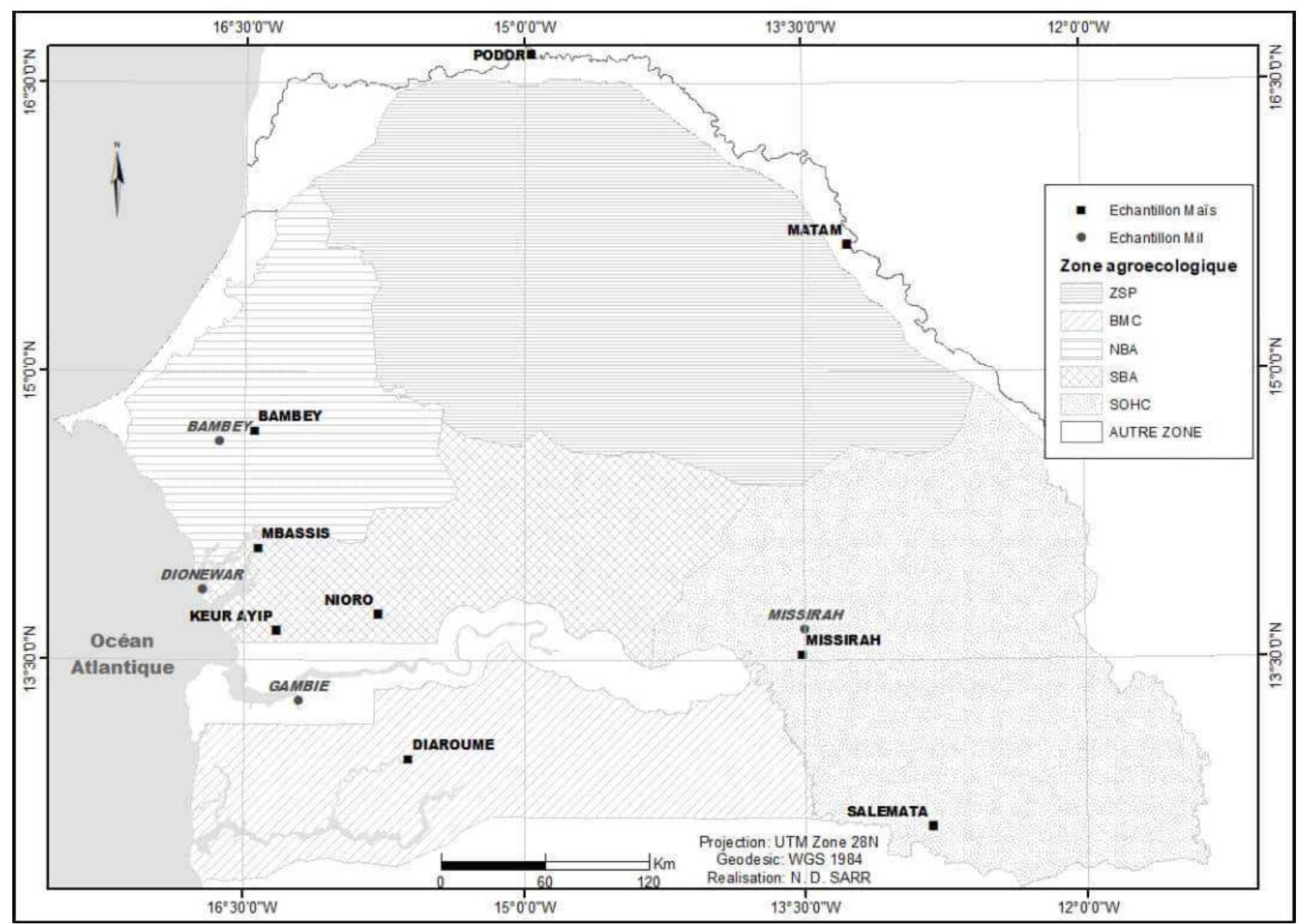

Figure 1. Sampling Localities.

\subsubsection{Harvesting Individuals}

Collecting maize and millet samples infested in the different AEZs, allowed to isolate individuals of Sitophilus zeamais for each zone and each host plant. It has been used in storage facilities where grain is highly vulnerable to infestation, but also in marketing places where there is a high chance of encountering infested maize from different AEZs.

After isolation, individuals from each AEZ and each host plant are placed in tubes containing $96 \%$ alcohol.
To code individuals compared to their host plant, we capitalized the first letter of the insect's genus name and then we specified the type of host plant of the individual using the first two letters of the plant (The first letter in upper case and the second in lower case), we have specified the locality of origin by 2 letters too (the first letter in upper case and the second in lowercase), then specify the serial number. Example a Sitophilus zeamais individual who was harvested in Bambey on Millet with the order number 12 is coded as: 
SMiBa12 if it was on maize, the code would be SMaBa12.

Table 1 summarizes the localities of the AEZs where the harvests took place, the number of individuals sampled for each AEZ, the geographical coordinates of the localities and the codes of the individuals.

Table 1. Sampling locations.

\begin{tabular}{|c|c|c|c|}
\hline Agro-Ecological Zones & Number of individuals & GPS & Sampling code \\
\hline NBA & 23 & & \\
\hline Bambey & $12 / 11$ & $14^{\circ} 42^{\prime} 00^{\prime \prime} \mathrm{N} / 16^{\circ} 27^{\prime} 00^{\prime \prime} \mathrm{W}$ & $\mathrm{SMaBa} / \mathrm{SMiBa}$ \\
\hline SBA & 47 & & \\
\hline Mbassis & 12 & $14^{\circ} 04^{\prime} 60^{\prime \prime} \mathrm{N} / 16^{\circ} 25^{\prime} 60^{\prime \prime} \mathrm{W}$ & $\mathrm{SMaMb}$ \\
\hline Nioro & 07 & $15^{\circ} 48^{\prime} 55^{\prime \prime} \mathrm{N} / 13^{\circ} 45^{\prime} 37^{\prime \prime} \mathrm{W}$ & $\mathrm{SMaNi}$ \\
\hline Dionewar & 09 & $13^{\circ} 52^{\prime} 60^{\prime \prime} \mathrm{N} / 16^{\circ} 43^{\prime} 60^{\prime \prime} \mathrm{W}$ & SMiDio \\
\hline Missirah & $12 / 13$ & $13^{\circ} 41^{\prime} 00^{\prime \prime} \mathrm{N} / 16^{\circ} 30^{\prime} 01^{\prime \prime} \mathrm{W}$ & SMaMi/SMiMi \\
\hline Salemata & 10 & $12^{\circ} 37^{\prime} 60^{\prime \prime} \mathrm{N} / 12^{\circ} 49^{\prime} 00^{\prime \prime} \mathrm{W}$ & $\mathrm{SMaSa}$ \\
\hline $\mathrm{BMC}$ & 20 & & \\
\hline Gambie & 10 & $13^{\circ} 27^{\prime} 09^{\prime \prime} \mathrm{N} / 16^{\circ} 34^{\prime} 40^{\prime \prime} \mathrm{W}$ & SMiGa \\
\hline Diaroume & 10 & $13^{\circ} 03^{\prime} 19^{\prime \prime} \mathrm{N} / 15^{\circ} 38^{\prime} 34^{\prime \prime} \mathrm{W}$ & SMaDi \\
\hline TOTAL & 125 & & \\
\hline
\end{tabular}

\subsection{Molecular Method of Analysis}

\subsubsection{DNA Extraction}

The extraction is the DNA release technique of the cell. It includes the individualization of cells (digestion) and the destruction of their plasma and nuclear membranes (lysis).

The digestion of the cells consisted of placing their paws and prothorax into tubes containing ATL buffer and $\mathrm{K}$ proteinases. After incubation, the tubes were centrifuged to separate the supernatant from cell debris.

To destroy the cell membranes, first cell lysis buffer (AL) was added, then some ethanol $(96 \%)$ after incubation into the tubes. Then the tubes are transverse in silica membrane columns. Finally, the centrifugation of the tubes allowed to retain the DNA on the siliceous membranes of the columns because negatively charged.

\subsubsection{DNA Purification}

The tubes DNA was purified by adding 2 buffers AW1 and AW2 in each column. After Centrifugation of the tubes and precipitation of the DNA at the bottom, the buffers and contaminants are discarded. The columns are then replaced in other tubes in which buffer $\mathrm{AE}$ has been added to unhook the DNA. The DNA is thus removed and stored at $-20^{\circ} \mathrm{C}$.

\subsubsection{PCR of the Mitochondrial Gene Cytochrome B}

The PCR of the mitochondrial gene Cyt. B was carried out by two primers

CB1 (5'TATGTACTACCATGAGGACAAATATC-3') and CB2 (ATTACACCTCCTAATTTATTAGGAAT-3'). For each sample (tube), the amplification was made from a total volume of $25 \mu 1$, of which a mixed volume of $23 \mu 1$ and a volume of $2 \mu \mathrm{l}$ of DNA extract. The mixed volume was constituted by: $18.3 \mu \mathrm{l}$ of milli water, $2.5 \mu \mathrm{l}$ of $10 \times$ buffer, $1 \mu \mathrm{l}$ of additional $\mathrm{MgCl}_{2}, 0.5 \mu \mathrm{l}$ of Dntp, $0.25 \mu \mathrm{l}$ of each primer and $0.2 \mu \mathrm{l}$ of Taq polymerase.

The conditions under which the PCR was performed are as follows:

1. The DNA strands were first separated with a temperature of $94^{\circ} \mathrm{C}$ for 3 minutes. This first denaturation was followed by 35 denaturation cycles of 1 minute at the same temperature.

2. The synthesis of complementary strands (elongation) was made at $72^{\circ} \mathrm{C}$ for 10 minutes. After amplification, the fragments are sent to a South Korean company for sequencing.

\subsubsection{Bioinformatics Analyzes}

The sequences were corrected and aligned by the Clustal software implemented in the Bioédit version 7.2.5 program.

The evaluation of the sequence diversity was made from some parameters that the DNAsp software made it possible to calculate. These are on the one hand, standard indices of genetic variability, such as parsimonious or singleton variable sites, the number of invariable sites, and the number of haplotypes, and on the other hand Haplotypic diversity $(\mathrm{Hd})$ and nucleotide diversity (Pi). These two indices have the distinction of highlighting the diversity and divergence of haplotypes.

\section{Results and Discussion}

\subsection{Results}

72 individuals were harvested specifically on maize and 53 exclusively on millet. Our dataset thus counts 125 sequences of size $410 \mathrm{bp}$. The exploitation of these sequences revealed overall a similarly low polymorphism rate of the two global populations of Millet and of Maize, with respectively $8 \%$ and $12 \%$ of polymorphic sites.

Insects subservient to maize have more haplotypes (21), sparingly variable sites (34) than the population insects subservient to millet, which are characterized by 10 haplotypes, and more invariable sites (376) and singleton sites (22). The substitution rates of the two populations are similar (Table 2). 
Table 2. Variability Parameters of Cyt. B of the two populations of Millet and of Maize.

\begin{tabular}{|c|c|c|c|c|c|c|c|}
\hline \multirow{2}{*}{$\begin{array}{l}\text { Host } \\
\text { Plants }\end{array}$} & \multirow{2}{*}{$\begin{array}{l}\text { Number of } \\
\text { individuals }\end{array}$} & \multirow{2}{*}{$\begin{array}{l}\text { Number of } \\
\text { haplotypes }\end{array}$} & \multirow{2}{*}{$\begin{array}{l}\text { Number of } \\
\text { sites }\end{array}$} & \multirow{2}{*}{$\begin{array}{l}\text { Invariables } \\
\text { Sites (\%) }\end{array}$} & \multicolumn{2}{|l|}{ Variables Sites } & \multirow{2}{*}{$\begin{array}{l}\text { Substitution } \\
\text { Rate }\end{array}$} \\
\hline & & & & & Singleton (\%) & Parcimony informative (\%) & \\
\hline & & & & & $12 \%$ & & \\
\hline Maize & 72 & $21(29 \%)$ & 410 & $88 \%$ & $\begin{array}{l}33 \% \\
8 \%\end{array}$ & $67 \%$ & 0,938 \\
\hline Millet & 43 & $10(23 \%)$ & 410 & $92 \%$ & $65 \%$ & $35 \%$ & 0,949 \\
\hline
\end{tabular}

The haplotypic diversity (Figure 2a) is approximately equal and high for the two global populations of millet and of maize, with respectively values of 0.837 and 0.813 . There is also no significant difference in nucleotide diversity (Figure 2b) (Maize: 0.18, Millet: 0.13). Nevertheless, haplotypes subservient to millet are genetically more convergent because their nucleotide diversity is lower than that haplotypes subservient to maize.

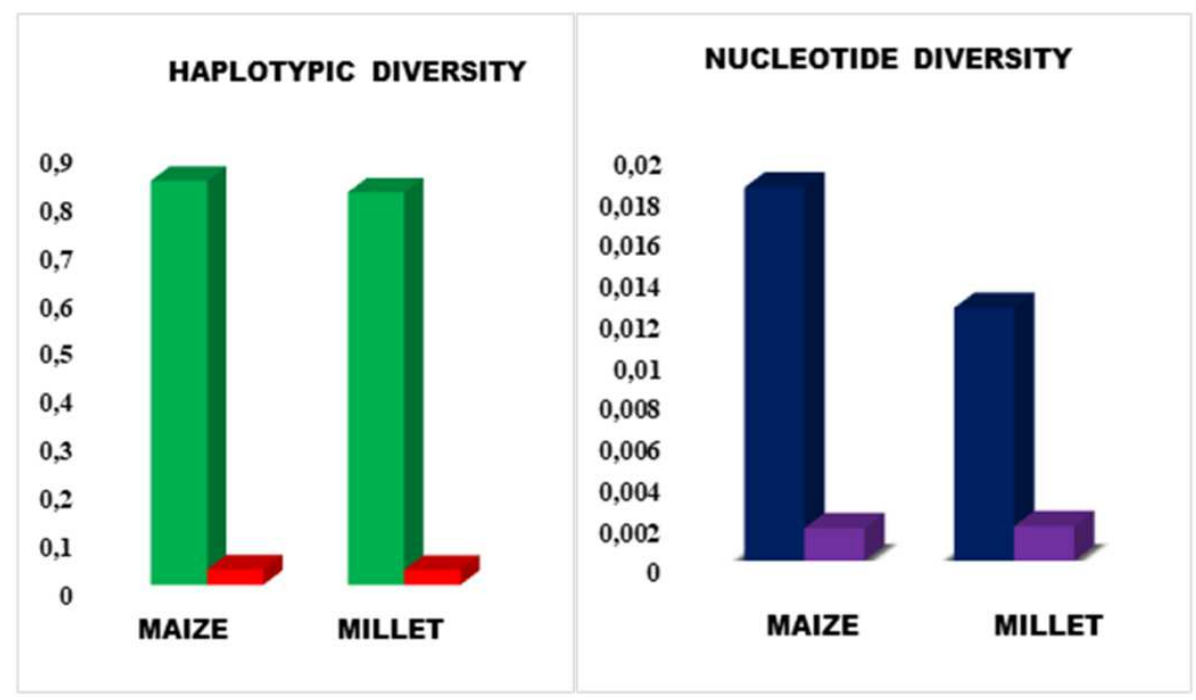

Figure 2. Genetic diversity of the two populations of Millet and of Maize.

If we compare the genetic diversity of the populations of Millet and Maize in the agroecological zones (AEZ), we find that those of the populations of the NBA and of the BMC are relatively similar, except the $\mathrm{Hd}$ which is weak for the maize population of the BMC. In contrast, Sitophilus zeamais populations of host plants are highly divergent in AEZs of
SBA and of SOHC, where Hd and Pi populations of Mille are null while those of Maize are high (Table 2).

Table 2 indicates that haplotype and nucleotide diversity, haplotype numbers, average number of nucleotide differences in millet and maize populations are approximately identical in NBA and in BMC AEZs. This is not the case in other AEZs.

Table 3. Genetic diversity of populations of Millet and maize in agroecological zones.

\begin{tabular}{|c|c|c|c|c|c|c|}
\hline AEZ & PGV HP & Number of individuals & Number of haplotypes & Haplotypic Diversity & Nucléotide Diversity & MPD \\
\hline \multirow{2}{*}{ NBA } & Maize & 12 & 4 & $0,561 \pm 0,154$ & $0,015 \pm 0,005$ & 6,182 \\
\hline & Millet & 11 & 5 & $0,618 \pm 0,164$ & $0,007 \pm 0,004$ & 3,091 \\
\hline \multirow{2}{*}{ SBA } & Maize & 12 & 5 & $0,667 \pm 0,141$ & $0,014 \pm 0,003$ & 6 \\
\hline & Millet & 9 & 1 & $0,000 \pm 0,000$ & $0,000 \pm 0,000$ & 0 \\
\hline \multirow{2}{*}{$\mathrm{SOHC}$} & Maize & 10 & 3 & $0,378 \pm 0,181$ & $0,001 \pm 0,002$ & 0,6 \\
\hline & Millet & 13 & 1 & $0,000 \pm 0,000$ & $0,000 \pm 0,000$ & 0 \\
\hline BMC & Maize & 10 & 3 & $0,378 \pm 0,181$ & $0,004 \pm 0,002$ & 1.8 \\
\hline
\end{tabular}

AEZ=AgroEcological Zone. $\mathrm{PGV}=$ Parameters Genetic Variability. HP=Host Plants. MPD=Mean number of Paire Differences.

\subsection{Discussion}

The maize population has a low number of haplotypes, a low polymorphism and substitution rate. The millet population expresses these same characteristics. This similarity reflects a genetic convergence between milletdependent insects and maize-specific insects. Similar values of haplotypic diversity and to a lesser extent of the nucleotide diversity of the 2 populations would be a guarantee that the host plants are subservient by the same haplotypes or genetically very close haplotypes. No genetic study of this insect on its 2 host plants has been done, either in Senegal or in Africa in the broad sense of the term. Nevertheless, a study of the genetic distribution of an insect named Caryedon serratus according to 5 host plants (Arachis hypogaea, Bauhinia rufescens, Cassia sieberiana, Piliostigma reticulatum) was carried out. She revealed besides a genetic structuring of the insect according to these 5 host plants [11]. 
The existence of an ancestral and majority haplotype (H2) shared between the host plants accredits this sharing of genes between millet and maize. Farmers tend to farm millet and maize in the same fields or in neighboring fields. This cultural practice favors the infestation of host plants by the same insects. This infestation is favored by the use of the same storage means. Indeed, the transfer of grain from one AEZ to another can be accompanied by the transfer of larvae, cocoons or even adults able to flourish in an AEZ that is not previously infested [15]. The high $\mathrm{Hd}$ and low $\mathrm{Pi}$ values of the 2 populations may be the result of rapid growth in their small ancestral populations for which there was not enough time for high diversity between haplotypes. Exchange of individuals between host plants has not impacted the strong haplotypic and low nucleotide diversity of the global population, as it is the same insects that mingle with each other. In some agro-ecological zones such as SBA and SOHC, genetic convergence between millet and maize populations is not verified. The millet populations of these localities are individually formed from the same haplotypes. This situation is the result of sampling. Indeed, it was carried out at the end of the dry season, a lean period during which the need to satisfy family food needs considerably reduces the availability of cereals, not to mention the fall in cereal harvests in recent years because of a deficit rainfall. The corollary is therefore a reduction in the number of haplotypes in these areas. The decrease in the genetic diversity, especially nucleotidic populations of some agroecological zones and the global population is an asset in the fight against this pest of millet and maize, because it can lead to the loss of potential adaptations of the insect to environmental changes.

\section{Conclusion}

At the end of this study of the genetic diversity of Sitophilus zeamais, which concerned 53 individuals of insects subservient to the host plant millet and 72 subservient to the host plant maize, in 5 agroecological zones of Senegal, we have found that global and local populations of maize and millet have approximately the same genetic characteristics. Therefore these plants have the same influence on the adaptive potentials of the insect. Since no host plant has more genetic influence than the other, other studies can focus on grain characteristics, or the influence of the agroecological zones, to try to explain their differential susceptibility to Sitophilus Zeamais.

\section{References}

[1] Almeida F. C., Giannini N. P., Simmons N. B. and Helgen K. M. Phylogenetic Tree for Pteropus and Related Genera (Chiroptera: Pteropodidae). Molecular phylogenetics and evolution, 2014. 77C, 83-95.

[2] Arbogast B. S., Kenagy G. J., Comparative phylogeography as an integrative approach to historical biogeography. Journal of Biogeography, 2001. 28, 819-825.
[3] Berthier K., Charbonnel N., Galan M., Chaval Y. \& Cosson J. F. Migration and recovery of the genetic diversity during the growing density phase in cyclic flies Populations. Molecular Ecology, 2006 15, 2665-2676.

[4] Berthier K., Galan M., Foltete J. C., Charbonnel N. \& Cosson J. F. Genetic structure of the cyclic fossorial water flies (Arvicola terrestris): landscape and demographic influences. Journal of Molecular Ecology, 2005. 14, 2861-2872.

[5] Chala NAFKHA, S. EZZEDDINE, B. CHEMMAM, O. JARDOUI and K. FADHLAOUI-ZID: Analysis of the cytochrome $b$ gene of mitochondrial DNA in Octopus octopus VULGARIS (CEPHALOPDA, OCTOPODA) of North and South Tunisian coasts. p. 35-36; P. 38-40. Vol. 41 p.

[6] Diome T., Ndiaye A., Ndong A., Doumma A., Sanon A., Ketoh G. K., Sembene M. Genetic identification of West African ecotypes of the groundnut seed-beetle Caryedon serratus Ol., (Coleoptera, Chrysomelidae) - South Asian Journal of Experimental Biology, 2011. 1 (2): p. 88-93.

[7] Diome T., Thiaw, C., Sarr, M., Ndong, A., Kane, M., Cisse, N., Sembene, M. Genetic diversity of Tribolium castaneum (Herbst) population in storage infrastructures and agro ecological zones in Senegal. Int. J. Biosci. 9, 248e258. Donnelly, P., Tavare, S., 1986. The ages of alleles and a coalescent. Adv. Appl. Probab. 18, 1e19.

[8] Diome T., Thiaw C., Ndong A., Sarr M., Kane M. \&Sembene M. Haplotype diversity of Tribolium castaneum $\mathrm{H}$. (Coleoptera, Tenebrionidae) pest of stored millet in Senegal. Journal of cell and animal biology. 6 (13), 2012: 192-199.

[9] Doadrio I., Carmona J. A. Phylogenetic relationships and biogeography of the genus Chondrostoma inferred from mitochondrial DNA sequences. Molecular Phylogenetics and Evolution, 2004 33, 802-815.

[10] Dubut V., Martin JF, Gilles A., Van Houdt J., Chappaz R., Costedoat C. (in press) Isolation and characterization of polymorphic microsatellite loci for the dance complex: Leuciscus (Teleostei: Cyprinidae). Molecular Ecology Resources, 2009 doi: 10.1111/j.1755-0998.2009.02594.x.

[11] Mbacké S., Kébé k., Delobel A. Effet structurant de la plante hôte sur la bruche de l'arachide, Caryedon serratus. Biotecnol. Agron. Soc. Environ. 2012 (1) 3-11.

[12] Farias, I. P., Orti G., Sampaio I., Schneider H., Meyer A. The Cytochrome b Gene as a Phylogenetic Marker: The Limits of Resolution for Analyzing Relationships Among Cichlid Fishes. Journal of Molecular Evolution, 2001, p. 5389-103, New York.

[13] Isman Abdi b. Diversity and genetic structuring of the populations of a devastating insect of stocks of millet in Senegal: Tribolium castaneum Herbst (Coleoptera: Tenebrionidae). Memory of master of Genetics of the populations, University Cheikh Anta Diop of Dakar, 201229 p.

[14] Kvitschal. Genetic diversity and population structure of sweet cassava using simple sequence repeat (SSR) molecular markers. African Journal of Biotechnology, 12 (10), 2013: 1040-1048.

[15] Momar Talla G. Efficacy of powdered maize cobs against the maize weevil Sitophilus zeamais in stored maize in Senegal. International Journal of tropical insect science, 2012, Vol. 32, No. 2, 94-100. 
[16] Ndong A, Diome T, Ndiaye A, Kébé K, Thiaw C, Douma A, Ketoh G, Sanon A and Ndong A, Kébé K, Thiaw C, Diome T and Sembene M. Genetic Distribution of the Cowpea (Vigna Unguiculata (L.) Walp) Bruchid (Callosobruchus Maculatus F., Coleoptera, Bruchidae) Populations in Different AgroEcological Areas of West Africa. J. Anim. Sci. Adv., 2 (7), 2012: 616-630.

[17] Sembene M. Several haplotypes of groundnut (Arachis hypogaea L.) seed-beetle, Caryedon serratus Ol. (Coleoptera: Chrysomelidae, Bruchinae), in West Africa: Genetic identification using $28 \mathrm{~S}$ sequences. Afr. J. of Biotechn., 10 (55), 2011: 11409-11420.

[18] Sembène M, Rasplus JY, Silvain JF and Delobel A. Genetic differentiation in sympatric populations of the groundnut seed beetle Caryedon serratus (Coleoptera: Chrysomelidae): new insights from molecular and ecological data. Int. J. Trop. Insect Sci., 28 (3), 2008: 168-177.

[19] Sembène M, Kébé K, Delobel $A$ and Rasplus JY. Phylogenetic information reveals the peculiarity of Caryedon serratus (Coleoptera, Chrysomelidae, Bruchinae) feeding on Cassia sieberiana DC (Caesalpinioideae). Afr. J. of Biotechn., 9, 2010: 1470-1480.

[20] Sezonlin Michel. Phylogeography and genetic of the populations of the borer of cereal stems drank olafusca (fuller) (will Lepidoptera, noctuidae) in sub-Saharan Africa, implications for the biological fight against this insect. Thesis of doctorate of the University of Paris XI-Orsay, 2006 152p.

[21] Tamura K., Peterson D., Peterson N., Stecher G., Nei M. et Kumar S. - "MEGA5: Molecular Evolutionary Genetics Analysis using Maximum Likelihood, Evolutionary Distance, and Maximum Parsimony Methods". Mol. Biol. Evol. 28 (10), 2011: 2731-2739.

[22] Trematerra P (2009). Preferences of Sitophilus zeamais to different types of Italian commercial rice and cereal pasta. Bulletin of Insectology, 62 (1): 103-106. 